\title{
KHILAFATISM IN ISLAM: THE CONCEPT OF THE CHILAFAH IN THE VIEW OF HIZBU TAHRIR AND AHMADIYAH
}

\author{
Muhammad Syaoki \\ Universitas Islam Negeri Mataram \\ syaoki@uinmataram.ac.id
}

\begin{abstract}
After the collapse of the Ottoman dynasty in Turkey, khilafatism became a prolonged polemic in the Islamic world. This polemic gave rise to various movements including Hizb ut-Tahrir which emerged in Palestine and the Ahmadiyya which emerged in India. This research is a type of literature study using qualitative methods. The results of this study indicate that although these two movements have completely different theological views, they both carry the idea of a caliphate even though in practice these two movements have different fighting directions. Khilafatism in Ahmadiyah has been running for a long time and survived, while khilafatism in HT is still a kind of utopia because until now there has not been a single region that has implemented a caliphate system, especially in Indonesia after the establishment of HTI as a banned mass organization.
\end{abstract}

Key Words: Khilafhatisme, Hizbut Tahrir, Ahmadiyah

\section{A. Background}

Khilafatism is a concept that wants the formation of an Islamic power that is headed directly by a Caliph. The caliph in the view of the result of apathy is a representative of God Who enforces God's laws on earth. The separatist movement is generally motivated by the desire to re-create Islamic forces which are centered in one command called the Caliph.

This desire is based on the system of government that has been implemented in Islamic history, especially after the death of the Prophet Muhammad. At that time the Islamic leadership was taken over by Abu Bakr through a fairly tough deliberation process so that Abu Bakr was elected to hold the highest position of power in Islam, even though Abu Bakr did not call himself a Caliph because power during the time of Khulafaur Rashidin 
was based more on the personal abilities of his friends. The Prophet's companions were Abu Bakr Umar Uthman and Ali. ${ }^{1}$

After the end of the Khulafaur Rasyidin era, Islamic leadership continued by the Umayyad dynasty and the Abbasid dynasty. The Umayyad dynasty was centered in Spain. While the Abbasid dynasty was based in Iraq. Although these two dynasties had led Muslims for quite a long time, both the Umayyads and the Abbasids were considered not to be characteristics of a pure caliph because of the process of transferring power from one caliph to another through an inheritance system or based on descent and not based on the competence of each individual.

The process of changing leadership in Islam in its history has not been through blood growth because the orientation of power is no longer on how to advance Muslims but how to seize power and maintain it. Such conditions became the forerunner of the decline of Islamic civilization in the Middle Ages. After the collapse of Islamic hegemony in the process and gave birth to many kinds of thoughts to carry out reforms in the Islamic world, several figures not infrequently proposed the rebirth of coconut with various variants.

Several contemporary Islamic thinkers including Jalaluddin Al-Afghani, Rasyid Rida, and Al Kawakibi tried to offer the caliphate as a solution so that Muslims get out of the complicated problems they are facing, such as setbacks in the social, political, economic, and poverty sectors in various sectors. Some of these thinkers consider that there needs to be a new system that is a way out for the problems of the people today, especially Muslims in their view are being faced with the hegemony of Western countries with the democratic system that they offer not a few then making third world countries as victims of the progress they have made.

A different view was conveyed by another contemporary Islamic thinker, Ismail Raji Al Faruqi. Faruqi considered that we must be enforced based on the principle of willingness and uphold the principle of freedom. In

${ }^{1}$ Azyumardi Azra. 2016. Transformasi Politik Islam Radikalisme, Khilafatisme, Dan Demokrasi. Kencana (PrenadaMedia). 
Faruqi's view, even minority groups must be protected by the state in a Khilafah system. Therefore, khilafatism in Faruqi's view is not a theocracy but a nomocracy system where the law is the highest foundation for the administration of a country.

Therefore, this study wants to explore the views of two transnational Islamic movements, namely Hizb ut-Tahrir and Ahmadiyah which both carry the concept of caliphate. Both of these transnational movements have followers in various countries because of the idea of a caliphate that they advocate, although in its implementation there are quite significant differences.

\section{B. Hizbut Tahrir Khilafatism}

Hizb ut-Tahrir is an international political party with an Islamic orientation. This party makes Islam its ideology and principle of struggle. Therefore, this party makes Islam the main reference in law enforcement, solving problems in people's lives. The main goal of this party is to enforce Islamic law through state instruments.

Hizb ut-Tahrir was born in al-Quds Palestine in 1953. It was founded by a madrasa teacher named Shaykh Taqiyuddin Al-Nabhani. HT was born as a response to the downturn of the Islamic ummah caused by the hegemony of the West which colonized most of the Islamic countries in the 19th century AD. ${ }^{2}$

Although many movements have Islamic nuances, HT considers these movements to only exacerbate the situation because they are not in one command so they are easy to be resisted by the enemies of Islam. Some of the causes of the failure of these movements, according to HT, are: Islamic movements are not based on clear thoughts (fikrah) and methods (tariqoh). In addition, these movements also do not have the right solidarity and understanding. ${ }^{3}$

\footnotetext{
${ }^{2}$ Ihsan, Samarah. 2002. Biografi Singkat Taqiyuddin Al-Nabhani. Bogor: Al-Izzah Press.

${ }^{3}$ Taqiyudin Al-Nabhani. 2001. Al-Takattul Al-Hizbi. Hizb al-Tahrir.
} 
The birth of HT also aims to revive the Islamic ummah from adversity, as well as liberate the ummah from the secular state system and switch to an Islamic system by enforcing the Islamic State in all corners of the earth. With the establishment of the Islamic State, HT believes that government affairs can be carried out following the guidance of the Qur'an and Hadith. ${ }^{4}$

The Daulah Islamiyah referred to by HT will be realized through a caliphate system, where the Islamic government is under one command, namely the caliph who is in charge of running the country based on Allah's laws as contained in the Qur'an and hadith. Justice, welfare, and progress of the ummah according to HT will only be realized through the caliphate system. As long as the caliphate has not been established, the ummah will continue to be in decline.

Establishing a caliphate according to HT is a very urgent obligation considering that currently, the Ummah is in three main problems: first, the Islamic Ummah does not have a centralized leadership so that the Ummah is divided into small state groups which makes them easy to defeat. Second, the absence of a caliphate system makes God's laws not enforced consistently because of the absence of institutions that implement them. Third, the absence of a caliphate system makes Muslims negligent in carrying out Islamic da'wah to all corners of the world. ${ }^{5}$

In HT's view, any system of government in the world today other than the caliphate system is unacceptable. Even though according to HT, the democratic system is flawed because it separates religion and state life. Besides that, according to HT, the democratic system does not originate from Islam but is born from Western civilization which is currently carrying out hegemony over the Islamic world.

HT views that enforcing the Khilafah is the only way to implement Islamic law on earth. The point is that without a Khilafah, Islamic law will never be fully enforced. This is based on a hadith that reads "Whoever has

\footnotetext{
${ }^{4}$ Taqiyudin Al-Nabhani. 2001. Al-Takattul Al-Hizbi. Hizb al-Tahrir.

${ }^{5}$ Media Umat. 2015. “Tragedi 3 Maret 1924." 6-19 Maret 2015, 2015.
} 
pledged allegiance to a Khilafah and has given his hand and his baby, then let him obey according to his ability. Then if someone else comes who wants to take his power, cut off that person's neck."

The hadith clearly states the command to appoint and obey a leader or Caliph. In addition, the hadith also shows the command to fight anyone who wants to seize the power of the Caliph, therefore the hadith indicates the necessity of realizing only one Caliph. In carrying out its mission, HT applies a systematic da'wah method which consists of three stages:

First, the stage of coaching and cadre (tatsqif). This stage aims to produce cadres who have Islamic beliefs as the forerunner to the formation of a party. At this stage, the HT movement is focused on gathering as many supporters as possible from the community. The small groups that were formed were then fostered with an intensive halaqah system. ${ }^{6}$

Tatsqif is the stage of building and strengthening the foundation of Hizb ut-Tahrir by increasing its supporters through halaqah-halaqah activities which aim to introduce Islamic thought which they have adopted intensely. This activity is expected to give birth to militant HT cadres.

Through the halaqah, regeneration is formed in stages starting from the beginner level to the musyrif. Cadres who have just joined will be put into the beginner level who is mentored by a mushrif. If the novice cadres are deemed loyal enough, their level will be raised to Darisin and have the right to participate in halaqah more intensively. It is at this level that a cadre is judged to have reached the tatsqif stage (guidance and cadre). ${ }^{7}$

The second, the interaction stage (tafa'ul). At this stage, the cadres who have been formed through the tatsqif stage interact with the ummah so that the ummah wants to make Islamic laws a guide in carrying out their lives.

\footnotetext{
${ }^{6}$ Halaqah is a method of instilling HT values through small group studies. In the beginning, they can follow the general ihalaqah, that is, ihalaqah which is designated for those who are still early and can be followed in general. iFurthermore, after a few months or according to the observations of imusyrif $\mathrm{i}$ (supervisor/supervisor), the participant in the general ihalaqah will be raised to status as idarisin $\mathrm{i}$ and has the right to follow the ihalaqah ihalaqah $\mathrm{i}$ ihalaqah under guidance.

${ }^{7}$ Al-Wa'ie. 2005. Mengenal Hizbut Tahrir.
} 
In this second stage, HT conducts intensive and targeted guidance through halaqah to build a framework for HT thinking, as well as increasing supporters with HT personality. The cadres formed are expected to be able to carry out Islamic da'wah in every activity of upheaval of thought and political struggle.

In addition, coaching is also carried out by disseminating ideas about Islamic law that are in line with HT's views. These ideas were disseminated widely and then the recitation of recitations in mosques, meeting halls, and offices, including through newsletters and mass media which were distributed regularly, and books were distributed free of charge. The aim was to build the collective awareness of the people through continuous interaction.

The next stage, namely the turbulence of thought (al-syira 'al-fikr) this turbulence of thought is carried out by fighting various ideological beliefs, thoughts, and ideas that are contrary to Islam. This upheaval of thought is carried out by uncovering errors or errors or counter-arguments against the ideas that are considered heretical.

At this stage, a political struggle (al-kifah al-siyasi) was also carried out by fighting against imperialist infidel countries that colonized Islamic countries and then freeing Islam from all forms of colonialism and destroying the conspiracy of western countries against Muslim co-Muslims other than This struggle is also carried out against other Islamic countries that run a government system that is not under Islamic teachings. This struggle is carried out by exposing their crimes as well as criticizing them so that they are in line with Islamic ideology.

The last stage of the tafa'ul stage is to adopt the benefit of the people by determining the number of the benefits of the people to serve all their affairs under Islamic law. Third, the stage of receiving power (istilam al-hukm) in this stage HT receives a mandate from the ummah to apply Islam as a state system and run life. 
The last stage of the HT struggle is the stage of acceptance of power or istilam al-hukm. It is at this stage that Islam can be applied in its entirety (kaffah). Because this stage is the most important stage in the history of the Prophet's struggle, namely when he succeeded in establishing an Islamic State with the Medina Charter. HT views that it is only in this caliphate that Islamic law can be applied comprehensively and comprehensively, not only partially.

\section{Ahmadiyah}

Ahmadiyah as a religious movement was first founded by Mirza Ghulam Ahmad who was born in Qadian, Punjab, India in 1835 AD. His father, Mirza Ghulam Murtada, was descended from Haji Barlas, a king in the Qesh region. ${ }^{8}$ At the age of 41 , namely in 1889 , Mirza Ghulam Ahmad claimed to have received a revelation that became the beginning of the birth of this movement. Mirza Ghulam Ahmad was crowned by his followers as al-Masih al-Mahdi.

The Ahmadiyya movement in its subsequent development was divided into two groups, namely the Qadian Ahmadiyya and the Lahore Ahmadiyya. What distinguishes the Ahmadiyya of the Kodian sect and the Ahmadiyya of the lava sect is that the Qadian Ahmadiyah believes that Mirza Ghulam Ahmad is the prophet and apostle of Imam Mahdi or the Messiah who was promised his coming by God. Meanwhile, the Lahore Ahmadiyya considered Mirza Ghulam Ahmad only as a reformer or mujadid, but not as a prophet and apostle that the Qadian Ahmadiyya believed (Nasution 1992). Referring to the differences between the two Ahmadiyah sects, the Qodian sect has extreme attitudes and beliefs, while the Lahore group is more moderate. ${ }^{9}$

Both schools of Ahmadiyah are active in doing da'wah through institutions and also write a lot of works. Even their writings have penetrated national borders. Because of their progressive attitude, these two schools have many followers in various parts of the world. In Surayawan's notes,

\footnotetext{
${ }_{9}^{8}$ Zulkarnain, Iskandar. 2005. Gerakan Ahmadiyah Di Indonesia. Yogyakarta: LKiS ${ }^{9}$ ibid
} 
currently, the number of Ahmadiyah followers worldwide has reached more than 200 million people and already has international branches in almost 178 countries (Al and Surabaya 2018).

\section{Ahmadiyya-style Khilafatism}

The Ahmadiyya's understanding of the concept of a caliphate, both the Qadian and Lahore schools, are both based on the verses of the Koran. However, they differ in their interpretation. The different views of the two are as follows: According to Mirza Basyiruddin Mahmud Ahmad, the words of the Caliph or successor in the Qur'an are used in three senses:

a. Khalifah is used for prophets who seem to be a substitute for Allah in the world. For example, Prophet Adam is called the Caliph (Sura al-Baqarah 31-32) and Prophet David is also called the Caliph (Surah Shod 38:27).

b. The caliph is defined as the people who come later, as in QS Al A'raf 70 and 75 . The caliph in this sense, namely as the successor of the prophet, was chosen by his own people. An example is the Caliph Abu Bakr who succeeded the Prophet, Muhammad.

c. The caliph was used as a successor to the prophet because they followed in the footsteps of the prophets before them. Such caliphs can be appointed by God just as a prophet appointed by God himself. Caliph who has the rank of prophet This is an assistant to the prophet who existed before or in his time. For example, Aaron was the caliph for Moses. (Surat al-A'raf 7:143).

In essence, all caliphs in the first and third sense are just spiritual leaders. Among the many prophets and apostles mentioned in the Qur'an, only a few people became spiritual leaders as well as government leaders. Prophets Harun, Zakaria, Yahya, and Isa are 
only spiritual leaders. ${ }^{10}$ They have never been the ruler of a point state while Prophet Muhammad SAW was a prophet and at the same time the holder of the reins of government. The caliphs who succeeded him, so Abu Bakr Umar Bin Khattab, Uthman bin Affan, and Ali Bin Abi Talib, also became heads of government.

According to Ahmadiyah, after Mirza Ghulam Ahmad died in 1908, the Khilafah was established in the Ahmadiyya Community, which was later known as Khalifatul Masih. The Khalifatul Masih doctrine is based on Mirza Ghulam Ahmad's own will about the existence of a caliph after his death and is also based on the hadith of the prophet which describes the nature of a caliph compared to the ruler of the state.

"There will be prophethood in you as long as Allah wills so that there is a dot then Allah will raise it. Then there will be a Khilafah on the pattern of prophethood as long as Allah wills it to exist. Then Allah will raise it to a point, then there will be an absolute kingdom and it will exist as long as Allah wills it to exist. Then Allah lifts it. Then there will be an absolute kingdom and it will exist as long as Allah wills so that it exists. Then Allah raises it to a point then there will be a meeting with a prophetic pattern of dots Then he is silent. HR Ahmad and Baihaqi.

What the Prophet Muhammad said has happened in the history of Islam according to the Ahmadiyah point after the caliphate or prophetic pattern or better known as the Rashidiyah caliphate which began with Caliph Abu Bakr and ended with Caliph Ali, then came the caliphate which began with the kingdom of Muawiyah. and ended with the Sultanate of Abdul Hamid II in Turkey. And after that, according to the words of the Prophet Muhammad, what file will appear again with a prophetic pattern, Yani, the second

${ }^{10}$ Muhtador, Moh. 2017. "Khilafah Islamiyah Perspektif Ahmadiyah (Sebuah Gerakan Spiritual Keagamaan)." Esoterik 2 (1). https://doi.org/10.21043/esoterik.v2i1.1959. 
prophetic pattern in the Isha period and the Mahdi. So in 1908, the coconut of the Messiah was established from the Ahmadiyya Community. This Khilafah is based on a prophetic pattern because the result is that he will continue the work of Mirza Ghulam Ahmad who is still dead, and Imam Mahdi who has the rank of a prophet.

The context of the relationship between politics and Islam or vice versa according to Ahmadiyah lies in the purpose of the revelation of religion, namely to uphold the truth and prevent hostility and continue to be with humanity. So the most basic goal for all heavenly religions is to carry out social justice. Therefore establishing a state is part of a religious empire that achieves one goal, namely social justice by using political power in addition to building preaching and special abilities that always have to cooperate with political forces.

In this paradigm, Ahmadiyah is very thick with political content in the sense that it has a specific goal through a guide that is carried out systematically, therefore it also carries the concept of caliphate.

The Ahmadiyya Khilafah is based on the belief that Mirza Ghulam Ahmad emerged as a true messianist, a reformer who seeks to reform the order of values and belief systems that are considered to deviate from the teachings of the Qur'an and the prophet Muhammad. Ahmadiyya is based on the saying of the Prophet Muhammad which reads that Allah will raise for this ummah at the beginning of each century a person who will influence his religion for him.

Ahmadiyah believes based on the hadith that it sends someone a reformer every reformer era that is what is called a renewal movement in Islam in these last days the movement is called Ahmadiyah. So Ahmadiyya is a reform movement within Islam.

The development of the caliphate was carried out by the Ahmadiyah through an organizational process, an internal 
consolidation of the movement which is carrying out a system of reform in the world Islamic community. Amadiyah struggles only to defend and broadcast Islam through five branches of Islamic da'wah activities outlined by mujaddid in the book of Fathi Islam ${ }^{11}$, namely:

1. Compile essays or books and publish them.

2. Broadcasting brochures and announcements followed by discussion and discussion.

3. Direct communication with visitors holding lectures and taklim assemblies.

4. Correspondence with those who seek or reject the truth of Islam

5. Bai'at

After the concept of allegiance is implemented, the militancy of the membership of the Ahmadiyya Community can be maintained to fight in the way of Allah. This model of allegiance characterizes that the Ahmadiyya movement is political rather than an organization engaged in religious reform. For Ahmadiyah, the caliphate system that must be established is the Khilafah ala Minhaji Annubuwah, so that means that this caliphate is religious, not political.

For the Ahmadiyya, the caliphate system was formed to destroy some of the obstacles that confront Muslims in developing Islamic requirements. The first obstacle that must be fought by the people as a way to the caliphate is the problem of restoring the confidence that the infidels had previously tried to remove from the minds and hearts of the people.

Ahmadiyah uses a cooperative approach to the authorities or official government to support the efforts that will be carried out by the Ahmadiyah congregation or at least where it can exist at the national level political arena.

${ }^{11}$ Asep Burhanudin. 2006. Ghulam Ahmad Jihad Tanpa Kekerasan. Yogyakarta: LKiS 


\section{Analysis}

\section{Movement form}

The concept of the Ahmadiyya caliphate is not political. This is what distinguishes Ahmadiyah from the Hizb ut-Tahrir (HT) movement which also carries a similar concept. But what HT is promoting is a political caliphate. The main difference between the two caliphs is very basic. The political caliphate presupposes the existence of an area, a clear area, which is guarded by the armed forces.

The spiritual caliphate is completely different. Ahmadiyah members can live anywhere and are subject to the government of the country where they live. However, their hearts and souls were subject to spiritual authority, namely the sole caliph who now resided in London. The spiritual caliphate does not need the territory. What is needed is a heart that is willing to submit and obey authority.

The concept of the Ahmadiyya caliphate is not political. This is what distinguishes Ahmadiyah from the Hizb ut-Tahrir (HT) movement which also carries a similar concept. But what HT is promoting is a political caliphate. The main difference between the two caliphs is very basic. The political caliphate presupposes the existence of a territory, a clear territory, which is guarded by armed forces.

Hizb ut-Tahrir's caliphate is clearly different considering that in its basic regulations, it is regulated that the Caliph as the extension of God on earth acts as the absolute ruler by holding full rights in constitutional affairs, where the results of the ijma cannot be contested by the people who want to criticize. The people do not have the right to vote in criticizing the emir because they feel it has tarnished the authority of God. This condition seems to return the concept of our government return to the dark era of European kingdoms where the hegemony of the Pope and king is full of power and is considered flawless.

The Ahmadiyya congregation can live in any country but is always subject to the laws in force in that country and has absolutely no 
aspirations to replace the laws of that country with Islamic law. Even though they live separately in territories, in the implementation of their religious doctrine, they are subject to the teachings or doctrines of the Caliph who is currently based in London. Therefore, the implementation of the Ahmadiyya-style Khilafah system is more of a spiritual Khilafah or spiritual Khilafah.

\section{Movement orientation}

The political conception of HT and also HT departs from the concept of religio-politics. Namely a political conception based on religious thought. With this conception, HT understands Islam from a political perspective. According to HT, politics does not only refer to the establishment of state institutions but also the formation of Islamic society as a whole. Therefore, politics is placed within an ideological framework, so that Islam is understood as an ideology (Tanjung 2018). Within the ideological framework, Islam, which was originally a religion, has been expanded to become the rules of life, both concerning spiritual life to socio-political life.

At this point, Islam as an ideology then provides a pattern for the realization of ideological values which HT calls ikrah and tariqah. Fikrah is Islamic thought based on the Islamic creed and sharia. While tariqah is a method of applying Islamic rules in Islamic ikrah. In this Islamic tariqah, HT bases the major goals of Islamic politics in the political khittah siyasiyah) which is driven by a political strategy (uslub siyasiyah). As the main political goal, khittah has not changed from the beginning to the end of the tariqah.

However, as a strategy, political uslub may change according to changing conditions. HT's political khittah is the formation of Islamic society with the establishment of a caliphate as the culmination of the Islamization of that society. To get there, strategic uslubs are needed that direct the khittah so that it can be achieved ideally. (Hizb ut-Tahrir, 2009:1118). HT's political uslubs that have occurred since cadre, 
socialization to the people, wars of thought, to the strategy of overthrowing power towards the establishment of a caliphate dawlah. It's just that in the middle of the road, political uslub may vary, to maintain the political khittah. ${ }^{12}$

The Ahmadiyya's conception of a caliphate is closer to a spiritual caliphate because their movement is not oriented towards a political caliphate. This fact is reinforced by the existence of Ahmadiyah congregations in various countries without disturbing the existence of the country where they live. However, submission to the caliph as the highest leader is still carried out even though the congregation is separated by the territorial boundaries of a State.

The Ahmadiyya caliphate concept is the antithesis of all the khilafatism conceptions in the contemporary Islamic movement. This is because the concept of the Ahmadiyya caliphate is completely separated from the political conception. Movements to enforce the caliphate in contemporary Islamic conceptions always make politics a means of struggle and enforcement of the Shari'a as their main goal. Meanwhile, Ahmadiyah can live anywhere by following the laws in force in the local country. This also makes the position of Ahmadiyah in various places not face to face with the State.

In some Western countries, such as England, Ahmadiyya is growing rapidly, and even that country has become the center of Ahmadiyya without receiving resistance from the government. In that country also Ahmadiyah grew and developed by establishing many mosques that held Friday prayers and became places of worship for other Muslims even though they were not members of the Ahmadiyya Community.

Even if in some places the Ahmadiyah gets resistance from the surrounding community, it is based more on differences in theological

${ }^{12}$ Rafiuddin, Mohamad. 2015. "MENGENAL HIZBUT TAHRIR (Studi Analisis Ideologi Hizbut Tahrir Vis a Vis NU)." Islamuna: Jurnal Studi Islam 2 (1): 29. https://doi.org/10.19105/islamuna.v2i1.653. 
views, especially regarding the problem of prophethood. The Ahmadiyya believe that Mirza Ghulam Ahmad is a prophet as the successor to the prophetic teachings of the Prophet Muhammad (ala minhajinn nubuwwah) (Asep Burhanudin 2006). Meanwhile, the Muslim community believes that Prophet Muhammad is the last prophet and there is no prophet after him.

This rejection of the Ahmadiyah movement occurs in countries where the majority of the population is Muslim, such as Indonesia and Malaysia. Meanwhile, Ahmadiyya can live and carry out their movement in countries where the majority of the population is non-Muslim, such as India, Britain, and France.

For Ahmadiyah, the caliphate is only in charge of regulating the life of the Ummah which is oriented towards spiritual values. According to Ahmadiyah, the Khilafah is not related, let alone dealing with the state system in one place, but is part of the spiritual and religious system. ${ }^{13}$ This is because the authority of the caliph in Ahmadiyah's view has been mandated by Allah so that the members must obey and obey the orders of the caliph which is currently held by Mirza Masroor Ahmad in London, England.

Meanwhile, Hizb ut-Tahrir received a lot of rejection in various countries. In Indonesia, this organization is even categorized as a prohibited organization with the issuance of Perppu No/02/Tahun/2017 concerning the disbandment of the Hizbut Tahrir Indonesia (HTI) organization because it is considered a threat to the existence of the Unitary State of the Republic of Indonesia (NKRI). (Indonesia 2017).

Thus it can be said that the resistance to these two movements is different in terms of the subject. Ahmadiyah faced more resistance from the public more because of theological issues, meanwhile, Hizb ut-Tahrir

${ }^{13}$ Asep Burhanudin. 2006. Ghulam Ahmad Jihad Tanpa Kekerasan. Yogyakarta: LKiS 
received resistance from the state because their political movements were considered to threaten the integrity of the state.

Meanwhile, in the Ahmadiyya perspective, the main task of a caliph is to improve aqidah, worship, and morality. This is as contained in the Koran which teaches about life. The second task of the caliph is to build the unity of the Muslim congregation on a global scale. When reviving an economic system that is more just than the capitalist or communist economic system (Asep Burhanudin 2006). Fourth, develop science with mastery of science. As has been achieved in the golden age of Islam.

Thus what is meant as khalifatullah in the Qur'an is a leader who regulates human life following the teachings of Allah in the Qur'an. The task carried out by a caliph is the same as the task carried out by the prophets and apostles. The similarity lies in their function as leaders of the people who replace God on earth. Therefore, in Ahmadiyah terminology, the Caliph is called Khilafat ala Minhaj nubuwwah. So whoever the caliph after Mirza Ghulam Ahmad, his first task is to be the successor of the prophet's struggle as an extension of the implementation of prophetic duties.

This high obedience to the caliph is a manifestation of the implementation of God's Word in the Qur'an surah al-Baqarah verse 4. This verse is a reference for the Ahmadiyya Community who believes that a caliph has absolute authority so that whatever is ordered by the Caliph must be carried out. The death that carrying out the caliph's orders means carrying out Allah's orders. This also makes the Ahmadiyya Jama'at have high loyalty to their religious doctrine so that there is almost no internal conflict within the movement of the Ahmadiyya Jama'at because they have one command which is run simultaneously by the entire Jama'at.

Thus it can be said that HT does not recognize the term separation of religion from the state. In HTI's view, religion and the state 
are one unit that supports each other, so that to be able to implement religious laws in the social life of the community, state instruments are needed. Implementing religious law must be based on state instruments so that a religious state is formed where religion and state can run with each other in harmony.

Meanwhile, Ahmadiyah considers that practicing religion does not have to go through state instruments, because religion is a personal matter, so even without state instruments, religion can still be practiced. This also makes the Ahmadiyah feel no interest in building a religious state because for them the state is a worldly affair that can be carried out based on various interpretations of strategy or politics in Islam. Even if in the Ahmadiyah doctrine there is a caliph or caliphate, the existence of the caliph will not interfere with the existence of any country because they are not carrying out a political mission to form a state of their own.

This fact is interesting considering that the debate about political Islam is a debate that never ends. Some try to unite religion with the state. Some others try to separate religion and the state. The two Khilafah systems introduced by Ahmadiyah and the heart are two models of the perspective of Islamic movements in understanding the relationship between the Islamic-Religious-Political way.

\section{E. Conclusion}

Khilafatism in the views of HT and Ahmadiyah has quite a sharp difference. HT wants the establishment of a daulah Islamiyah (caliphate) in a special area that consistently and thoroughly applies Islamic law as the basis of the state. HT views that Islamic law will only be enforced if it is implemented through state instruments or the caliphate. Meanwhile, according to Ahmadiyah khilafat is a spiritual khilafat that does not require a certain area. Ahmadiyya Khilafatism can exist in any area but is still subject to one command, namely the caliph, especially in matters related to religion. The Ahmadiyya caliphate has been going on for a long time, while the HT 
caliphate is still only a concept because no region has yet implemented the HT-style caliphate system.

\section{References}

Al-Wa'ie. 2005. Mengenal Hizbut Tahrir.

Al, Stai, and Fithrah Surabaya. 2018. "Ideologi Kaum Santri: Studi Atas Narasi Kurikulum Pesantren Salaf Iksan Kamil Sahri” 6 (1): 85-105.

Asep Burhanudin. 2006. Ghulam Ahmad Jihad Tanpa Kekerasan. Yogyakarta: LKiS.

Azyumardi Azra. 2016. Transformasi Politik Islam Radikalisme, Khilafatisme, Dan Demokrasi. Kencana (PrenadaMedia).

Ihsan, Samarah. 2002. Biografi Singkat Taqiyuddin Al-Nabhani. Bogor: Al-Izzah Press.

Indonesia, Republik. 2017. "Peraturan Pemerintah Pengganti Undang-Undang Republik Indonesia Nomor 2 Tahun 2017."

Media Umat. 2015. “Tragedi 3 Maret 1924." 6-19 Maret 2015, 2015.

Muhtador, Moh. 2017. "Khilafah Islamiyah Perspektif Ahmadiyah (Sebuah Gerakan Spiritual Keagamaan).” Esoterik 2 (1). https://doi.org/10.21043/esoterik.v2i1.1959.

Nasution, Harun. 1992. Pembaharuan Dalam Islam. Jakarta: Bulan Bintang.

Rafiuddin, Mohamad. 2015. "MENGENAL HIZBUT TAHRIR (Studi Analisis Ideologi Hizbut Tahrir Vis a Vis NU)." Islamuna: Jurnal Studi Islam 2 (1): 29. https://doi.org/10.19105/islamuna.v2i1.653.

Tanjung, Indra Utama. 2018. "Studi Komparative Pendirian Negara Khilafah Di Indonesia." Jurnal Penelitian Medan Agama 9 (1): 111-40.

Taqiyudin Al-Nabhani. 2001. Al-Takattul Al-Hizbi. Hizb al-Tahrir.

Zulkarnain, Iskandar. 2005. Gerakan Ahmadiyah Di Indonesia. Yogyakarta: LKiS. 